\title{
Editorial
}

\section{The Role of Stem Cells in Obstetrics and Gynecology}

\section{Gita Pratama}

Stem cells are undifferentiated cells that can divide to produce offspring cells (self-renewal) that continue as stem cells and also can differentiate into multiple mature cell types (become specialized) when required. Stem cells could develop into blood, skin, brain, bones, fats and all organs in the human body. They could repair and regenerate injured cells and might potentially treat many medical conditions. Sources of stem cells basically can be divided into embryonic stem cells and adult stem cells. Due to ethical concern and the possibility for tumour formation, research on embryonic stem cells is very limited. On the contrary, research using adult stem cells is increasing every year, especially on mesenchymal stem cells. Adult stem cells can be obtained from various sources such as bone marrow, blood, fats and also readily available from gestational tissues such as umbilical cord, amnion and placenta. $^{1-3}$

Research on stem cells such as in vitro, using an animal as disease's model and also clinical trial to human is currently undergone for therapeutic purposes for many diseases. To date, most of the stem cells therapy is in the form of clinical research not commercially available yet for patients, unless for some indications with hematopoietic stem cells. Unfortunately, we also know that there are industries which offer unproven stem cells therapy for patients. Unproven stem cells therapy can be unsafe and harmful to vulnerable patients. In Indonesia, it is clear that the law regulates such stem cells therapy and before considered as standardized service therapy, doctors should perform any therapy with stem cells under research which should be approved by the ethics committee. ${ }^{4}$

In the field of Obstetrics and Gynecology, stem cells research has been done for several conditions such as stress urinary incontinence, pelvic floor prolapse, uterine and vaginal reconstruction. ${ }^{5-8}$ Other studies, mainly using the animal model and few human studies, have looked for stem cells therapy for primary ovarian insufficiency. ${ }^{9-12}$ Few studies also addressing stem cells therapy for endometrial disorders, such as thin endometrium and Asherman's syndrome. ${ }^{13,14}$ The results of the studies are varied, some shows the potential use of stem cells for Ob/Gyn conditions and some do not. Therefore, to date, there is no stem cells therapy, apart from research, that has been approved to be a standardized therapy for patients with Obstetrics and Gynecology problems. More studies and evidence are needed before we can integrate stem cells into our daily practices. 


\section{REFERENCES}

1. Los MJ, Skubis A, Ghavami S. Stem cells. Los MJ, Hudecki A, Wiechec E, eds. Stem Cells and Biomaterials for Regenerative Medicine. Academic Press. 2019: 5-16.

2. Poulos J. The limited application of stem cells in medicine: a review. Stem Cell Res Ther. 2018;9:1-11.

3. Zakrzewski W, Dobrzynski M, Szymonowicz M, Rybak Z. Stem cells : past, present, and future. Stem Cell Res Ther. 2019;10:1-22.

4. Peraturan Menteri Kesehatan Republik Indonesia nomor 32 tahun 2018 tentang penyelenggaraan pelayanan sel punca dan/atau sel. 2018.

5. Smaldone MC, Chen ML, Chancellor MB. Stem cell therapy for urethral sphincter regeneration. Minerva Urol Nefrol. 2009;61:27-40.

6. Tillman BW, Yazdani SK, Lee SJ, Geary RL, Atala A, Yoo JJ. The in vivo stability of electrospun polycaprolactonecollagen scaffolds in vascular reconstruction. Biomaterials. 2009;30:583-8.

7. Maruyama T, Masuda H, Ono M, Kajitani T, Yoshimura Y. Human uterine stem/progenitor cells: their possible role in uterine physiology and pathology. Reprod. 2010;140:11-22.

8. De Filippo RE, Bishop CE, Filho LF, Yoo JJ, Atala A. Tissue engineering a complete vaginal replacement from a small biopsy of autologous tissue. Transplantation. 2008;86:208-14.

9. Liu T, Huang Y, Zhang J, Qin W, Chi H, Chen J, Yu Z, Chen C, Transplantation of human menstrual blood stem cells to treat premature ovarian failure in mouse model. Stem Cells Dev. 2014;23:1548-57.

10. Wang Z, Wang Y, Yang T, Li J, Yang $X$, Study of the reparative effects of menstrual-derived stem cells on premature ovarian failure in mice. Stem Cell Res Ther. 2017;8: 11.

11. He Y, Chen D, Yang L, Hou Q, Ma H, Xu X. The therapeutic potential of bone marrow mesenchymal stem cells in premature ovarian failure. Stem Cell Res Ther. 2018;9:263-9.

12. Edessy M, Hosni HN, Shady Y, Waf Y, Bakry S, Kamel M. Autologous stem cells therapy, the first baby of idiopathic premature ovarian failure. Acta Med Int. 2016;3:19-23.

13. Hu J, Song K, Zhang J, Zhang Y, Tan B. Effects of menstrual blood-derived stem cells on endometrial injury repair. Mol Med Reports. 2019;19:813-20.

14. Azizi R, Aghebati-Maleki L, Nouri M, Marofi F, Negargar S, Yousefi M. Stem cell therapy in Asherman syndrome and thin endometrium: Stem cell-based therapy. Biomed Pharmacother. 2018;102:333-43 
